\title{
Determinants of Employees Performance in Corporate Sector: Case of an Emerging Market
}

\author{
Mubbsher M. Khan ${ }^{1} \&$ Maryam Jabbar ${ }^{2}$ \\ ${ }^{1}$ Institute of Business Administration, Quaid-e-Azam Campus, University of the Punjab, Lahore, Pakistan \\ ${ }^{2}$ University of the Punjab, Lahore, Pakistan \\ Correspondence: Mubbsher M. Khan, Quaid-e-Azam Campus, University of the Punjab, Lahore, Pakistan. Tel: \\ 92-42-9923-0800. Fax: 92-42-9923-1259. E-mail: mubbsher.khan@ibapu.edu.pk
}

Received: May 28, 2013

doi:10.5430/bmr.v2n3p25
Accepted: June 24, 2013

Online Published: July 5, 2013

URL: http://dx.doi.org/10.5430/bmr.v2n3p25

\begin{abstract}
The question of how to retain the existing employees is answered by attractive compensation, friendly leadership, balance between work life conflicts and healthy work environment. This study looks into this phenomenon by seeking empirical justification in this regard and considering the work-life conflicts, compensation, leadership and working conditions as main contributory factors towards employees' job performance. The goal of this research work is to answer the queries which prevail in the minds of employers in corporate sector of Pakistan due to various organizational factors which significantly influence the employees' job performance. The study identifies the those independent variables whose factors have significant effect on employees' motivation level and that in turn improve employees' job performance using original data collected from employees in eight companies. A 5-point Likert scale rated questionnaire was used to collect data from respondents. The scales used in the study were adopted from past research works and were based on five-point Likert scale. Convenience sampling technique was used to collect data from two hundred and forty respondents in Lahore, Pakistan. Out of two hundred and forty questionnaires distributed, only two hundred questionnaires were received back (Response rate $=83 \%$ ) which are used in the data analysis. The analysis entails that all the variables of the study prevail in corporate sector of Pakistan except the effect working conditions on employee job performance as shown by the insignificant correlation (.094) among working conditions and employee job performance. Independent variables such as leadership and compensation had a significant positive impact on the dependent variable, employee job performance $\left(.198^{* *} \& .157^{*}\right.$ respectively), whereas the independent variable of work-life conflicts had a significant but negative correlation $\left(-.147^{*}\right)$ with employee job performance. The most important evidence which this study purports, as far as it relates to an emerging market economy, is that working conditions has a weak an insignificant relation with employees' job performance.
\end{abstract}

Keywords: compensation, corporate sector, employees, employee productivity, human resource management, leadership, work-life conflicts, workplace

\section{Introduction}

Corporate sector in Pakistan is facing fierce competition as far as manpower is concerned. In such a competitive environment retaining existing employees is a daunting task when competitors are trying to attract employees from other organizations through offering attractive compensation plans, healthy workplace environment and lots more. While provision of such incentives build a sense of belongingness among employees it prevents them to switch from one organization to another and subsequently improves their job performance. That is very central for smooth and effective operation of an organization.

In subsequent sections the researchers present brief extracts from literature regarding the concerned areas, then come the methods employed to delineate the proposed research model, the hypotheses, research design and sampling design and finally the results, discussions and conclusion.

\subsection{Employee Performance}

Foundation for high performance must be investigated by the organizations. No organization can progress by one or two individuals' efforts; it is the combined effort of all the members of the organization. Performance is a major multidimensional concept aimed to achieve results and has a strong link to strategic targets of an organization. Employee performance means employee productivity and efficiency as a result of employee growth. Employee 
performance will impinge on the organization's performance. However the excellent working of the workforce at all levels of organization has a major influence on organization's performance.

Each employee's productivity has an impact on organization's goals therefore it is essential that each individual employee should be managed. Performance of the employees plays a key role for organizations. Employees are the asset for the organization. Organizations have learned the importance of the people in the organization in that without them the organization's objectives could not be accomplished.

\subsection{Working Conditions}

There are many factors in employees' workplace environment that greatly impact their level of enthusiasm and performance. The workplace's environment affects employee confidence, output and commitment - both positively and negatively. Therefore it is not just a coincidence that new incentive programs which focus on lifestyle changes, work/life balance, health and fitness issues were previously not considered as significant payback tactics, but are now common practices amongst well-reputed corporations, and primary considerations of potential employees.

The class of the employees' workplace environment highly affects their level of motivation and the following performance. How well they engage with the organization, especially with their workplace environment, influences to a great extent their error rate, level of innovativeness, relationship with other employees, rate of absenteeism and, finally how long they continue to work.

\subsection{Leadership}

A leader is the one who leads to an organization. He makes sure that the purpose for which an organization is made is fulfilled. In other words, a leader is one who is capable of moving the organization in the direction set by him which he deems fits.

While having certain leadership competencies and skills, a leader should have the ability to adapt to different leadership styles and behaviors to achieve organizational goals and objectives. At the individual level, leaders who are able to persuade, stimulate and direct employees will often be rewarded by devotion and performance of their employees (Mosadegh \& Yarmohammadian 2006). Leadership is an essential part of the activities of management of people and directing their efforts towards the goals and objectives of the organization.

\subsection{Compensation}

Compensation processes are based on compensation philosophies and approaches which are developed and supervised to give and sustain suitable types and levels of financial compensation (Bob, 2011). Armstrong (2005) argued that compensation management is a vital part of human resource management (HRM) and it moves toward organization's performance. It leads to design and implement compensation plans that are geared to the enhancement of organization and employee's productivity.

Importance of HR practices in under-developed countries has been recognized by Anakwe (2002). There are many variables which are included in HR practices but in this research work three HR practices are included which are compensation, promotion and performance evaluation. The main reason of selecting these three practices is based on fact represented by (Shahzad, Bashir, and Ramay, 2008) that in under-developed countries physiological requirements (compensation, promotion and performance evaluation) have significant influence on employees' performance.

Performance evaluation and promotion practices are usually based on standard criteria, actions and strategies and executed by capable and skilled employees of the organization. Employee perception about the equality of these practices counts a lot. Promotion is the acknowledgement of employees' efforts and his devotion to work. Every employee wants to receive rewards for his good performance.

Pakistan is an emerging market where Human Resource (HR) practices are required to be more visible in the organizations with an aim to improve performance of employees and organization together.

\subsection{Conflict}

Conflict is a major hazard for the workforce. In every business, conflict is a reality of life. When resources are limited and freedom is not available conflicts arise. Conflicts may happen within a team or divisions of the organization. Task conflict is one aspect of intra-group conflicts. It occurs when there is a disagreement among team members due to differences in their ideas and views on any issue related to a task. In fact conflict is essential to the life and dynamics of teams. Positive conflict has positive relationship with performance. While when negative 
conflicts arise, performance of employees is adversely affected, i.e. it has a negative relationship with employees' performance. Organizational conflict arises when organizational goals and ideas of teams collide with each other.

There are two kinds of conflicts namely horizontal and vertical conflicts. Horizontal conflict is that which occurs among members of teams or groups at the same level in the organization's hierarchical structure while vertical conflict is that which occurs among teams or groups at different level in the organization's hierarchical structure. The major objective of this research work is to originate and ascertain the aspects that have influence on employee performance.

\section{Material Studied}

\subsection{Employee Performance}

The performance is defined as the attained outcome of actions with the skills of employees who perform in some situation (Prasetya \& Kato, 2011). According to Suhartini (1995) employee performance is a mutual result of efforts, abilities and perception of tasks. Good performance is the step towards achievement of organizational aims. Hence more effort is required to improve the employee performance.

Dharma (1991) said that performance is something that is done or products formed and offered by a group of people. Swasto (1996) said that employee performance is the actions or the completion of errands that were done by individuals within specific period of time.

\subsection{Relationship Between Work Environment and Employee Performance}

Work environment can be made pleasant by controlling the noise, pollution, temperature, lighting and improving facilities to reduce physical risks. According to Yesufu (1984) in order to enhance employees' output a suitable work-environment is vital. If the environment of organization is excessively noisy, polluted, warm and ill ventilated, the employees' performance will be diminished.

The conditions at working environment may be favorable or unfavorable to the employees. In favorable conditions employees tend to share their pleasant experiences and express their true attitudes. In this environment the negligent employees tend to transform into those who feel a sense of accountability. In unfavorable conditions employees are likely to share their unpleasant experiences and in this environment the employees with a sense of accountability or rationalism tend to change into unaccountable and irrational employees. The most recognized theory is that when the working environment is suitable for employees they show better performance in the organization. When employees contribute better input then their output boosts accordingly and employee productivity also enhances.

\subsection{Relationship between Leadership and Employee Performance}

According to Cummings and Schwab (1973) employees must be committed to meeting organization's objectives instead of their personal objectives. According to Maritz (1995); and Bass (1997) good leadership is the most significant factor for monitoring, evaluating and encouraging the employee performance. Outstanding organization has outstanding leadership and growing organizations replicate their performance. According to Jones \& George (2000) leaders are efficient when they cast influence on their subordinates for accomplishing the organizational objectives.

According to Bass (1997) leadership is the most important aspect for determining organizational performance. Therefore it is important to know the leadership progress and its impact on employee performance. On the whole the intention is to check the leadership growth and its influence on employee performance.

\subsection{Relationship between Compensation and Employee Performance}

Compensation is the major element that affects the employee performance. If employees are satisfied that organization is offering a good compensation then their motivation is at a higher level and as a result their work performance is also better off. Robbins (2001) said that when employees feel happy about their compensation they are more motivated towards their work and the performance of the company also boosts.

Cameron and Pierce (1996) said that many organizations use pay, promotion and benefits to give more confidence to better performing employees. Management of the organization often anticipates this depending on the strengths and responsibilities of such employees and these expectations are different from organization to organization. Teseema \& Soeters (2006); and Shahzad et al. (2008) have described that there is a significant relationship among employee performance and compensation practices. 


\subsection{Relationship between Conflict and Employee performance}

Human resource management is considered the backbone of all business management practices. Today the human resource is considered the most valuable asset of any business. To improve the performance organizations are trying to improve the performance of this human capital. According to Cohen \& Single (2001) there is lot of pressure on the management of the organization to prove to be a friendlier one to the employees. Grover and Crooker (1995); and Scandura and Lankau (1997) have found that the employees' sense of responsibility to organization become more progressive when flexible time scheduling is being adopted by the organization.

Brandt, Krawczyk \& Kalinowski (2008) examined that the work-life balance relationship exhibits a negative correlation. According to Ali and Baloch (1999) conflict negatively affects the personal life of employees which results in their low performance. Ahmad (2008) also remarks that work and family conflict is inversely linked to employees' performance. It is also examined that work and family conflict decreases employee satisfaction, increases employees stress and decreases performance.

A lot of research has undertaken which holds that inverse relation exists between conflict and performance level of employees. Hence it is assumed that there is negative relation between conflict and performance level of employees in Pakistan.

\section{Methods}

\subsection{Problem Statement}

Today, the major concern of corporations is to understand and implement strategies that may enhance employees' job performance in order to get the desired results from them. This is becoming more challenging and difficult due to competitive nature of corporate environment. Existing literature indicates that factors such as attractive compensation, friendly leadership, balance between work-life conflicts and healthy work environment build a sense of belongingness among employees which prevents them to switch from one organization to another and subsequently improves their job performance which is very important for smooth and effective functioning of an organization. The main objective of this research work is to find the effect of factors of independent variables such as compensation, leadership, work-life conflicts and working conditions on employee job performance as a dependent variable.

\subsection{Research Model}

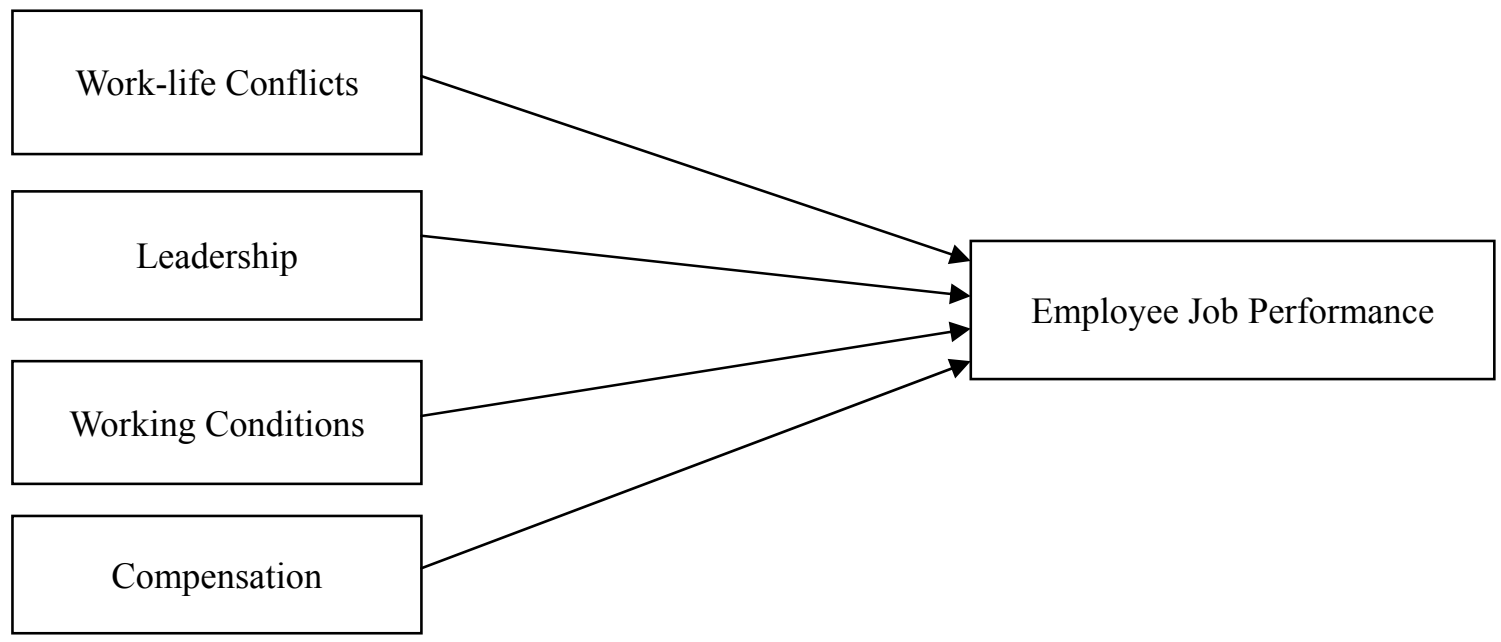

Figure 1. Theoretical Framework of the Study

\subsection{Hypotheses of the Study}

H1: Work-life conflicts have negative and significant impact on employee job performance.

H2: Leadership has a positive and significant impact on employee job performance.

H3: Working conditions have positive and significant impact on employee job performance.

H4: Compensation has a positive and significant impact on employee job performance. 


\subsection{Research Design and Sampling Design}

The population in this study consists of managerial and non-managerial employees working in corporate sector of Lahore, Pakistan. This population is quite large so sampling is done to save time and cost. Convenience sampling is used in this research study. Initially ten geographical clusters are identified within Lahore, then randomly four of these are selected and sixty questionnaires were sent to each cluster for filling. Out of a total of two hundred and forty questionnaires administered randomly, only two hundred yielded valid responses which are used in the final analysis of the study. The data collected is analysed to test the hypothesis, draw conclusions and solve the research question.

This research was conducted using a 5-point Likert scale rated questionnaire to measure all the variables of the study. There were subsets of 4-7 items about each independent variable which was to be filled by the employees. At the end was a subset items to be filled by the immediate bosses of employees. The results obtained from this questionnaire are easily analysable using statistical tools and techniques for which purpose SPPS was used. The variables under question are depicted in the shape of mean and standard deviation to see the strength of prevalence of these variables. At the end correlation analysis is conducted to establish relationships among variables and see the significance of the relationship between them. Reliabilities of the scales are tested (using Cronbach's Alpha) which were $.74, .80, .78, .64$ and .75 for leadership, compensation, conflicts, working conditions and employee job performance respectively. To ensure the validity of the data collected, the constructs used in the questionnaire were adopted from various past researches (i.e. scales of leadership, compensation, conflicts, working conditions and employee job performance were adopted from Northouse, 2001; Tessema \& Soeters, 2006; Netemeyer, Boles, and McMurrian, 1996; Moos, 1994; Jaworski \& Kohli, 1993 respectively) and the variables used in the study are the most relevant to investigate the phenomenon under consideration.

\section{Research Findings}

Table 1. Descriptive

\begin{tabular}{lccc}
\hline Variables & $\mathbf{N}$ & Mean & Std. Deviation \\
\hline Work-Life Conflicts & 200 & 3.3330 & .78177 \\
Leadership & 200 & 3.7907 & .65123 \\
Working Conditions & 200 & 3.4500 & .45183 \\
Compensation & 200 & 3.1133 & .68551 \\
Employee Job Performance & 200 & 3.5956 & .53937 \\
\hline
\end{tabular}

Table 1 shows the mean and standard deviation of the variables in the study. The descriptive shown in the table indicate that mean of work-life conflicts is 3.3330 with a standard deviation of .78177 , which shows that majority of employees are either neutral about effects which the factors of work-life conflict have on their performance or they somewhat agree that these factors have negative effect on their performance. The standard deviation of leadership is somewhat lower $(0.65123)$ with a mean score of 3.7907 which shows lesser variability of the responses and overall better reliability of the scores. From this it can be depicted that employees somewhat agree that their immediate bosses and head of their organizations have friendly relations with them as well as help keep the workforce morale high by encouraging the top performers.

Working conditions has a mean score of 3.4500 and an even lower standard deviation of .45183 , reflecting less inter response variability and that employees are overall neutral about the effects which the factors of their working condition has on their performance. The mean score of compensation is 3.1133 with a standard deviation score of .68 551. The variability is a bit higher in the responses as indicated by the standard deviation of compensation. It shows that employees are either neutral or dissatisfied for the compensation practices prevailing in their organizations.

In the last portion of questionnaire, the subset of items prepared to be filled by the immediate bosses of employees about their performance yielded the following results. The mean score of employee job performance come out to be 3.5956 with a standard deviation of .53937 which are almost consistent with the scores of above four variables of job performance and indicates that immediate bosses somewhat agree that their employees are aware about their job roles and perform all the assigned tasks effectively and efficiently. 
Table 2. Correlation Between Dependent Variable and Independent Variables

\begin{tabular}{lcccc}
\hline & $\begin{array}{c}\text { Work-Life }^{\text {Conflicts }}{ }^{\mathbf{b}} \\
\text { Employee Job }\end{array}$ & Leadership $^{\mathbf{b}}$ & $\begin{array}{c}\text { Working } \\
\text { Conditions }\end{array}$ & Compensation $^{\mathbf{b}}$ \\
$\begin{array}{l}\text { Performance } \\
\text { Sig. (2-tailed) }\end{array}$ & $-.147^{*}$ & $.198^{* *}$ & .094 & $.157^{*}$ \\
\hline$*$. Correlation is significant at the 0.05 level (2-tailed) & .005 & .026 \\
**. Correlation is significant at the 0.01 level (2-tailed) & \\
a. Dependent Variable \\
b. Independent Variables
\end{tabular}

Table 2 provides the Pearson's correlation coefficients between independent variables (work-life conflicts, leadership, working conditions and compensation) and dependent variable (employee job performance) of the study which are found using the SPSS 19. The construct of work-life conflicts has a weak correlation with employee job performance as provided by its correlation coefficient i.e. -.147 ( $\mathrm{sig}<.05$ ), thus we accept H1 which postulates that work-life conflicts have significant and negative impact on employee job performance.

On the other hand, constructs of leadership and compensation yield positive and significant correlation coefficients of .198** (sig <.01) and $.157^{*}$ ( $\mathrm{sig}<.05$ ) respectively which lead us to accept H2 and H4 which purports that there exists a positive and significant association of factors of leadership and compensation with employee job performance.

However the relationship between working conditions and employee job performance is found insignificant (although positive) as provided by its correlation coefficient i.e. .094, thus we reject $\mathrm{H} 3$ which specifies that working conditions have an impact on employee job performance.

This is the only finding which is not in conformity with the previous literature. There comes out an insignificant association of working conditions with employee job performance. This may be due to couple of reasons which may be that many previous researches on this construct have been done in developed countries whereas this research study has been conducted in an emerging market where workplace environment as well as employees' perceptions and expectations regarding their workplace are entirely different from those in developed countries.

\section{Discussions and Conclusion}

The goal of this research work is to answer the queries which prevail in the minds of employers in corporate sector of Pakistan due to various organizational factors which significantly influence the employees' job performance. In order to achieve this objective, the study identifies the a number of independent variables whose factors significantly impact employees' motivation level and that in turn improve employees' job performance. Authors originate their study on the fact that employees' work performance is influenced by various organizational variables like work-life conflicts, leadership styles of their immediate bosses, employees' perceptions regarding the workplace environment and compensation practices.

The most important evidence which this study purports, as far as it relates to an emerging market economy, is that working conditions has a weak an insignificant relation with employees' job performance, which is reflected through its correlation analysis of variables.

However in light of its correlation analysis this study is in agreement with past evidences which entail that imbalance between work and real life conflicts coupled with heavy workloads significantly decreases employees' job performance. On the other hand, efficient and friendly leadership motivates the employees towards the achievement of individual as well as organizational goals and subsequently improves their job performance. Similarly, healthy workplace environment makes the employees motivated and enhances their job satisfaction and performance. As far as the compensation practices are concerned, it has been witnessed that if employees think their employers are offering them a good compensation then their motivation level increases and as a result their performance to work also enhances.

Given the fact that findings of this study are in conformity with the existing literature, these are justifiable up to great extent. Therefore the relationships found in this study are important for their practical implications. The focus of 
management of an organization operating in an emerging market like Pakistan should be to design such strategies and policies which ensure proper and efficient implementation of the discussed factors so as to improve employee productivity and overall organizational performance.

It has been witnessed that in today's market-driven system, employees are not completely loyal to their respective employers. Today, all they need is the quality of benefits such as healthy workplace environment and appropriate compensation which satisfy their personal and family requirements effectively.

Hence the major need of today's organizations is to find the ways to create satisfied and loyal employee base that can't be eroded even in the face of severe competition. Therefore, these organizations must consider various antecedents of superior job performance in order to have happy and loyal employee-base which is very much important for the success of the company.

\subsection{Suggestions}

Individualized approach could be adopted by analyzing the demographic trends in the industry. The focus should be to provide the maximum value to the employees on individual level and demographic trends could reveal the standard of living patterns which the organization could exploit and take benefit from in order to make the employees satisfied and improve their job performance.

The corporation could provide attractive compensation and monetary incentives and healthy workplace environment to the workforce as this concept has the potential which can win the hearts of the employees and motivate them to deliver superior job performance; and in this way organizations could effectively snatch the market share pie from the jaw of its competitors through improved employee productivity and performance.

\subsection{Research Limitations}

This research has been conducted on eight related companies of Lahore. It can also be generalized to the whole corporate sector of Lahore or even to other urban and rural areas comprising the whole of Pakistan. But, up to this effort this research would have limited value.

Target population of the study was white collar employees with high level of qualifications. This study also might not be applicable to the sectors other than corporate sector. This study considers just four factors which have influence on employees' job performance i.e. work-life conflicts, leadership, working conditions, and compensation.

\subsection{Suggestions for Future Research}

Future research could be conducted in other sectors as well in order to verify the results of this study. Future research could be done by taking other variables such as advancement opportunities and self-recognitions which also have significant influence on employees' job performance.

Future research could also be done by including the lower level employees in the target respondents as they might better understand and subsequently responded to different questions asked in the questionnaire with minimum errors as compared to managerial level employees.

\section{References}

Ahmad, A. (2008). Direct and indirect effects of work-family conflict on job performance. The Journal of International Management Studies, 3(2), 176-180.

Ali, N., \& Baloch, Q. B. (2009). Predictors of Organizational Commitment and Turnover Intention of Medical Representatives (An Empirical Evidence of Pakistani Companies). Journal of Managerial Sciences, 3(2), 263-273.

Anakwe, U. P. (2002). Human resource management practices in Nigeria: challenges and insights. International Journal of Human Resource Management, 13(7), 1042-1059. http://dx.doi.org/10.1080/09585190210131285

Armstrong, M. (2005). A handbook of human resource management practices. UK: Kogan Page, p.986.

Bass, B. M., \& Avolio, B. J. (1997). Full range leadership: Manual for the multifactor leadership questionnaire. Palo Alto, CA: Mind Garden.

Bob, N. (2011). Making employees suggestions Count. Journal of personnel management, 17, 20-41.

Brandt, J., Krawczyk, R., \& Kalinowski, J. (2011). Personal And Work-Related Predictors Of Organizational Commitment And Life Satisfaction Of Slovak Women In Higher Education. College Teaching Methods \& Styles Journal (CTMS), 4(2), 7-14. 
Cameron, J., \& Pierce, W. D. (1996). The debate about rewards and intrinsic motivation: Protests and accusations do not alter the results. Review of Educational Research,66(1), 39-51. http://dx.doi.org/10.3102/00346543066001039

Cohen, J. R., \& Single, L. E. (2001). An examination of the perceived impact of flexible work arrangements on professional opportunities in public accounting.Journal of Business Ethics, 32(4), 317-328. http://dx.doi.org/10.1023/A:1010767521662

Cummings, L. L., \& Schwab, D. P. (1973). Performance in Organizations: Determinants and Appraisal. Glenview: Scott Foreman and Company.

Dharma, Agus. (1991). Gaya Kepemimpinan Yang Efektif Bagi Para Manajer [The Effective Leadership Styles for Managers]. Bandung: Sinar Baru.

Grover, S. L., \& Crooker, K. J. (1995). Who appreciates family-responsive human resource policies: The impact of family-friendly policies on the organizational attachment of parents and non-parents. Personnel psychology, 48(2), 271-288. http://dx.doi.org/10.1111/j.1744-6570.1995.tb01757.x

Jaworski, B. J., \& Kohli, A. K. (1993). Market orientation: antecedents and consequences. The Journal of marketing, 57(3), 53-70. http://dx.doi.org/10.2307/1251854

Jones, G. R., \& George J. M. (2000). Essentials of managing organizational behavior. Upper Saddle River: Prentice-Hall.

Maritz, D. (1995). Leadership and mobilizing potential. Human Resource Management, 10(1), 8-16.

Moos, R. H. (1994). Work environment scale manual: A social climate scale: Development, applications, research (3rd ed.). Palo Alto, CA: Consulting Psychologists Press.

Netemeyer, R. G., Boles, J. S., \& McMurrian, R. (1996). Development and validation of work-family conflict and family-work conflict scales. Journal of applied psychology, 81(4), 400-410. http://dx.doi.org/10.1037/0021-9010.81.4.400

Northouse, P. G. (2001). Leadership: Theory and practice (2nd ed.). Thousand Oaks, CA: Sage.

Prasetya, A. \& Kato, M. (2011). The Effect of Financial and Non Financial Compensation to the Employee Performance. The 2nd International Research Symposium in Service Management. Yogyakarta,Indonesia.

Rad, A. M. M., \& Yarmohammadian, M. H. (2006). A study of relationship between managers' leadership style and employees' job satisfaction.Leadership in Health Services, 19(2), 11-28. http://dx.doi.org/10.1108/13660750610665008

Robbins, S. P., (2001). Organizational Behavior, New Jersey: Pearson Education International.

Scandura, T. A., \& Lankau, M. J. (1997). Relationships of gender, family responsibility and flexible work hours to organizational commitment and job satisfaction. Journal of Organizational Behavior, 18(4), 377-391. http://dx.doi.org/10.1002/(SICI)1099-1379(199707)18:4<377::AID-JOB807>3.0.CO;2-1

Shahzad, K., Bashir, S., \& Ramay, M. I. (2008). Impact of HR practices on perceived performance of university teachers in Pakistan. International review of business research papers, 4(2), 302-315.

Suhartini, (1995). Analisis factor-faktor yang mempengaruhi intensi peningkatan kinerja dosen pada perguruan tinggi swasta Daerah Istimewa Yogyakarta [Analysis of factors affecting intention performance improvement lecturer at private universities in Yogyakarta] (Thesis). Surabaya, Program Pascasarjana Unair.

Swasto, Bambang. (1996). Pengembangan Sumber Daya Manusia Pengaruhnya Terhadap Kinerja dan Imbalan [Human resource development and its effect on performance and rewards], Malang: FIA Unibraw-Malang.

Teclemichael Tessema, M., \& Soeters, J. L. (2006). Challenges and prospects of HRM in developing countries: testing the HRM-performance link in the Eritrean civil service. The International Journal of Human Resource Management, 17(1), 86-105. http://dx.doi.org/10.1080/09585190500366532

Wall, B., Solum, R. S., \& Sobol, M. R. (1992). The visionary leader. Rocklin: Prima Publishing.

Webb, J. (2006). Leadership in KM and the Role of the CKO. Legal Information Management. 6, 267-270. http://dx.doi.org/10.1017/S1472669606000880

Yesufu, T.M. (1984). The Dynamics of Industrial Relations: The Nigeria Experience. Ibadan: University Press Limited. 